\title{
The role of Self-Help Groups' Structures in Uplifting the Livelihoods of Households in Nyakach Sub County of Kisumu County, Kenya
}

\author{
Paul Okello Atieno ${ }^{1}$, George Moseh $^{2}$, Nicholas K. Ombachi ${ }^{3}$ \\ ${ }^{1}$ Kisii University, Kenya \\ ${ }^{2}$ Muranga University of Technology, Kenya \\ ${ }^{3}$ Masinde Muliro University of Science and Technology, Kenya
}

\begin{abstract}
Joint liability lending strategy adopted by Self Help Groups (SHGs) has provided a panacea for financial exclusion previously associated with the rural poor. Access to SHG microcredit by the rural poor enables acquisition of assets for improved production as well as food and better livelihood. However, poverty levels in some regions in Kenya remain high despite the existence of several SHGs. There were about 796 registered self-help groups in Nyakach Sub-County by December 2015. In the study area, poverty level had moved from $18 \%$ to $43 \%$ in the period up to 2019 , representing $238 \%$ rise. The situation contradicts evidence from other developed countries across the globe especially parts of Asia and Europe which show that self-help groups have positive influence on the overall development of society. The purpose of the study was to explore how structures of SHGs influence livelihoods of households in Nyakach Sub County, Kenya. Specific objectives were to determine how types of SHGs influence livelihood of households; assess the influence SHG size has on the livelihood of households and to determine how objective based SHGs influence households' livelihoods. The theory of Collective Action (CA) stipulating that mobilization of groups of vulnerable population to fight a common problem which has been overlooked by responsible public institutions guided the study. Descriptive design was employed on a target population of 9450 from which a sample size of 384 respondents was calculated via Yamane's formula. Questionnaires and interview schedules were used to collect data from the SHG members whereas Key Informant interviews were used to collect data from Divisional Social Services Officers (DSSOs) who were non SHG members. Findings showed that financial and social capitals were the livelihood aspects highly influenced by structures of SHGs and the size and objective-based SHGs had high influence on livelihood of households. The influence of SHG structure on livelihood was significant but small $(n=384 ; r=.427$; $p<0.05)$. It was concluded that the influence of structure was not homogeneous. The study recommended that structures of SHGs should be aligned to contextual conditions of the household members.
\end{abstract}

Key words: Collective Action; Household; Livelihood; Self-Help Group; SHG Structure

\section{INTRODUCTION}

$\mathrm{T}$ he concept of Self-Help Group (SHG) gained traction during 1970s when Mohammad Yunus launched Grameen Bank in Bangladesh to implement a lending scheme for the poor (Agrawal, Thakur and Singh, 2016;De Hoop, Brody, TripathiVojtkova, and Warnock, 2019). Joint liability lending started up by Grameen Bank became the strength from which SHGs drew their lending activities to members (Armendariz de Aghion \& Morduch, 2005). The types of SHGs including their main activities as well as their gender, income level of the members, employment activities and composition has been a focus of researchers during the last four decades (Tiwari \& Arora, 2015). Formation of these groups have taken varying structures and characteristics, with majority of them tending to be composed of women (Kaur \& Bajwa, 2016), people of specific income level (Nithyanandhan \& Mansor, 2015), and people who pool together to achieve a specific objective such as enhanced farming activity, vending, or business (Rathinam \& Akter, 2014). It should be noted that whereas groups formed on the basis of such characteristics have attracted sufficient focus, inconsistencies have been noted in their outcomes.

The discussions of SHGs have leaned towards objective based structures more than size or type of organizations. In their work, Hossain, Maleky, Hossain, Reza and Ahmed, (2016) explored the role of agricultural credit on productivity and livelihoods of small, marginal, and landless tenant farmers in Bangladesh and found that impacts were heterogeneous over household's headship, tenancy status, and farm size. On their part, Rathinam and Victor (2014) examined the economic empowerment of the dairy dependent women Self-Help Group (SHG) members in Puducherry region in India and concluded that women were empowered when they took dairying as an Income Generating Activity (IGA). It seemed clear from Rathinam and Akter (2014) and Hossain et al (2016) that limited conclusive results have been forthcoming regarding influence of objective based SHGs on livelihoods of households.

Types of SHGs, whether women only or youth only groups, have also received a fair share of documentation. Fagan, Quinn-Gates, Rebsso and Cromie (2021) utilised a mixed method approach to examine the impact of Tearfund SHG membership on the psychosocial well-being of womens' SHGs in Ethiopia. Results showed that members of older 
SHGs reported statistically greater psychosocial well-being than those of the younger ones, although the inter-group differences were small but significant. Arguing on the same loan repayment, Ugbomeh, Achoja, Ideh and Ofuoku (2008) analysed determinants of loan repayment performance among women self-help groups in Bayelsa State, Nigeria. They revealed that women-headed households, interest rates and household size negatively and significantly affected the loan repayment performance while price stability of farm proceeds and commitment to self-help groups positively and significantly affected the loan repayment. However, besides the fact that studies covering types of SHGs have concentrated on groups associated with women, how these groups influence livelihood of households has not been highlighted clearly.

Self-help group size as an aspect of its structure which affects set goals has also attracted extant literature (Stella, Aggrey \&Eseza, 2014; Ofuan \& Izien, 2016). It is expected that the size of any SHG would determine the amount of subscription and loan repayment performance (Feroze, Chauhan, Malhotra and Kadian, 2011). A study by Beaman, Karlan, Thuysbaert and Udry (2014) revealed that large positive investment responses resulted into a reduction in liquidity constraints among SHG members in Mali. Another study by Atieno (2017) focusing on the impact of SHGs on asset acquisition among 25 market vendors in Kisumu revealed increased asset and income accumulation among members. However, whereas firm size had been closely associated with profitability and growth, scanty documentation tends to be available in the field of SHGs. Moreover, much seems not to have been covered regarding influence of SHG size on livelihood of members.

Livelihood has been described as comprising of the capabilities, assets (including both material and social resources) and activities required for a means of living (Carney, 1988, cited in Rahman \& Akter, 2014). The Sustainable Livelihoods Approach (SLA) developed by the British Department for International Development (DFID) in their cooperation development program since 1997 has at its core, the livelihoods of households (Scoones, 2009). It is however critical to note that how structure of SHGs have influenced livelihoods of households has not been accorded much attention. Furthermore, such focus would be significant in areas which, despite the existence of several SHGs, poverty incidents are still rampant.

Nyakach sub-county in Kenya has experienced a rise in the number of SHGs from 20 in 1980s to about 796 in 2015 (Republic of Kenya, 2019). At the same time, poverty level has moved from $18 \%$ to $43 \%$ in the same period, representing $238 \%$ rise (Republic of Kenya, 2010). Scores of researchers (Ugbomeh, Achoja, Ideh, and Ofuoku, 2008; Hossain et al, 2016; Fagan, Quinn-Gates, Rebsso, \&Cromie, 2021) have highlighted the virtue of SHGs in enhancing economic status of members particularly women. However, influence of SHG structure on the livelihoods of households in Nyakach Sub County henceforth becomes questionable.

\subsection{Statement of the Problem}

Emergence of self-help groups has been lauded as a panacea for solving financial problems previously associated with the rural poor. Through SHG micro-credit, members are able to acquire assets for production as well as food and improved nutrition. However, poverty levels in some regions in Kenya is alarming despite the existence of several SHGs. There were about 796 registered self-help groups in Nyakach Sub-County by December 2019 out of which 630 were registered after December 2015. In the study area, poverty level had moved from $18 \%$ to $43 \%$ in the period up to 2015 representing $238 \%$ rise. The situation contradicts evidence from other developed countries across the globe particularly parts of Asia and Europe which show that self-help groups have positive influence on the overall development of society. Against this backdrop, the study endeavoured to explore the role of SHG structure in uplifting the livelihoods of households in Nyakach sub county, Kisumu county, Kenya.

\subsection{Purpose of the Study}

The purpose of the study was to explore the role of Self-Help Groups' (SHGs) structure in uplifting livelihoods of households in Nyakach Sub County of Kisumu County, Kenya

\section{Specific Objectives}

i. To explore how SHG Type influences household livelihoods.

ii. To establish how SHG Size influences household livelihoods.

iii. To assess how Objective based SHGs influence household livelihoods.

\section{EMPIRICAL LITERATURE REVIEW}

Bharamappanavara and Jose (2015) examined the differences in the collective performance and the pattern of relationship of the individual characters, group variables and economic variables among the three micro-credit delivery models. The analysis was based on the data from 90 members from nine SHGs operating in three taluks in the Davanagere District of Karnataka state. The categorical regression revealed that cooperation, consensus among members, and knowledge on SHGs linkages and transparency in activities significantly influenced the collective performance. It had also been found that SHGs could improve their performance by creating awareness in its members on the SHG purpose and by giving regular updates of information.

In a similar fashion, Rathinam and Victor (2014) examined the economic empowerment of the dairy dependent women Self-Help Group (SHG) members in Puducherry region in India. The respondents were made into two groups by using wealth ranking: poor and better-off within the group. The study concluded that women were empowered when they took dairying as an Income Generating Activity (IGA). The relative advantage was observed more for the underprivileged women 
(widows, women whose husbands were sick) as it provided self-employment. The mean value of household assets, milk production and sale, and annual income of the women SHG members were increased in post SHG situations. The findings tend to portray inconsistency in as far as improvement in household livelihood from SHG participation across the sampled groups of women was concerned.

While looking at loan repayment among dairy farmers, Feroze, Chauhan, Malhotra and Kadian (2011) analysed the factors that influence the repayment performance of the SHGs in India, by conducting a study on a sample of 120 SHG members from 60 dairy SHGs and 60 non-members selected from the state of Haryana. Results showed that peer monitoring, group size and female percentage had positive influence, whereas homogeneity and loan amount had negative influence on the repayment performance of the SHGs. This study (Feroze et al, 2011) demonstrated that size of SHG was a major determinant of loan repayment, however, the relationship between group size and livelihood of household members was not discussed.

In a study conducted in Mali, Beaman, Karlan, Thuysbaert and Udry (2014) examined whether returns to capital were higher for farmers who borrow than for those who did not, a direct implication of many credit market models. They measured the difference in returns through a two-stage loan and grant experiment. Findings revealed large positive investment responses and returns to grants for a random (representative) sample of farmers, showing reduction in liquidity constraints. However, the study found zero returns to grants for a sample of farmers who endogenously did not borrow. They also found important heterogeneity, even conditional on a wide range of observed characteristics. However, Beaman et al (2014) did not show how livelihoods of households were improved through returns to capital in their study. Furthermore, they did not indicate the influence of contextual issues such as availability of other sources of income apart from farming.

Among women farmers in Nigeria, Ugbomeh, Achoja, Ideh and Ofuoku (2008) investigated the determinants of loan repayment performance among women self-help groups in Bayelsa State, Nigeria. Data was gathered from one hundred and twelve (112) women farmers in the area using the multistage sampling technique. Findings showed that womenheaded households, interest rates and household size negatively and significantly affected the loan repayment performance of women farmers while price stability of farm proceeds and commitment to self-help groups positively and significantly affected the loan repayment of women farmers in self-help groups in the area.

Mushumbusi and Kratzer (2013) used quantitative and qualitative data from three regions of Tanzania to explore whether women members of microfinance institutions (MFIs) were more empowered compared to non-members in nonprogram areas. The results showed a significant difference between the women members of MFIs and non-members in the dependent variables related to women empowerment. Women members of MFIs had more control over savings and income generated from the business, greater role in decisionmaking, greater self-efficacy and self-esteem and greater freedom of mobility and increased activities outside home.

Similarly, Fagan, Quinn-Gates, Rebsso \& Cromie (2021) used mixed methods to examine the impact of Tearfund SHG membership on the psychosocial well-being of womens' SHGs in Ethiopia. Period of membership (2 years and 5 years) were compared with standards of living. Results showed that members of older SHGs reported statistically greater psychosocial well-being than younger ones on standardised scales. The younger against older group differences were significant but small. A comparison as to whether the use of farmer-groups approach in agricultural information dissemination increases adoption of technologies and improved yields were carried out in Uganda. Findings showed that membership resulted into increase in banana and cassava yields but not in sweet potato, beans and maize. On the other hand, non-group members' sweet potato yields were higher than group members although not significant. Another study in Kenya by Atieno (2017) sought to establish the impact of SHGs on asset acquisition among women group members trading in open air markets in East Kolwa location of Kisumu East Sub County, Kenya. The study targeted 25 market trader groups operating in the area, comprising 375 members. Findings showed that all the respondents (100\%) of the SHG members had received at least one type of asset through membership, and $80 \%$ of them reported an improvement in asset acquisition.

It is worth noting that discussions on SHGs have elaborately focused upon access to credit and improvement in asset acquisition. Significantly, SHG structures such as women only groups, farmer groups, or groups based on specific number of members have been discussed in terms of their contribution towards improved access to credit, information access, and credit repayment performance. While it would be assumed that such SHG contributions would automatically lead to improved livelihood, limited attention seems to have been directed towards this discourse.

\subsection{Theoretical Foundation}

The study was founded on the theory of Collective Action (CA). The theory explains the act of mobilizing people around common problem to utilise the group's power for solving such a problem (Badejo, Majekodunmi, Kingsley, Smith and Welburn, 2017). Through collective action, the weak and marginalised are able to use their voice and demand for institutional change in order to improve their lives. Collective action revolves around two pillars: local problem-solving and increased social accountability to overcome cultural, political and institutional barriers to improve people's lives (Haile, Bock \&Folmer, 2012; Alison and Nambiar, 2013). Collective action has been seen as a force behind women's 
empowerment movements to solve problems of exclusion, gender-based violence and child marriage. According to Alison and Nambiar (2013), absence of CA is a significant contributor to experiences of disempowerment for the less fortunate populations. Indeed, Bharamappanavara and Jose (2015) have argued that due to joint efforts towards loan collection, credit repayment in most SHGs has experienced improved performance over the years.

\subsection{Conceptual Framework}

The theory has it that the instrumental and intrinsic aspect of collective action embedded in SHGs are essential to their transformative power to the poor in the society (Alison \& Nambiar, 2013). Pooling together and joint lending strategies enable SHG members to engage in complex web of activities using their acquired capital to improve their livelihood (Scoones, 2009). The study therefore conceptualized that SHGs formed by collective action influence livelihoods (reflected in acquired assets or capital) of households in Nyakach Sub County. Figure 1represents the conceptual framework of the study.

Independent Variable

Dependent Variable

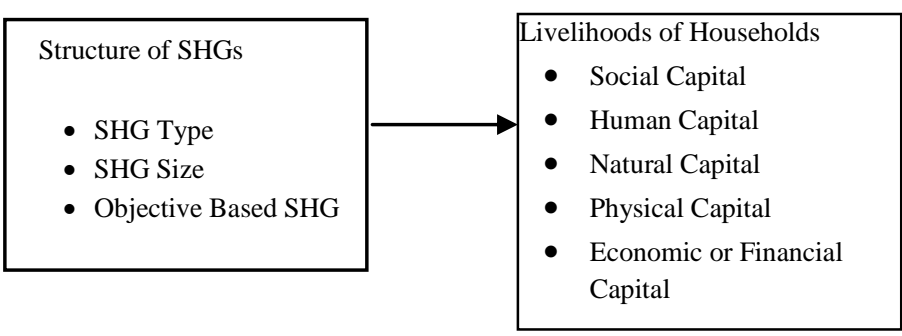

Figure 1: Relationship between SHG Structure and Livelihood of Households

The conceptual framework illustrated in Figure 1 indicates that the structure of SHG is denoted by type of the group (women, youth, or mixed), size of the group (number of members etc.), and groups based on achieving particular objective like farmer-based or business-based. These influence the dependent variable: livelihoods of households' members in terms of their social capital, human capital, natural capital, physical capital, and economic capital.

\section{METHODOLOGY AND MATERIALS}

\subsection{Research Design}

This study adopted descriptive survey design comprising mixed-methods approach utilizing both quantitative and qualitative methods of data collection and analysis. Mixed methods approach involves gathering both numeric information using questionnaires as well as text information using interviews so that the final database represents both quantitative and qualitative information (Creswell, 2012). This design fitted the study since it sought to describe how SHG structure influences livelihood of the members in terms of acquisition of capital.

\subsection{Study Area}

The study location was Nyakach sub - County of Kisumu County, Kenya. The area borders Lake Victoria to the East and lies to the $0.4 \mathrm{~S}$ latitude and $35 \mathrm{E}$ Longitudes. It has a mean annual rainfall of between 1000-1500 mm (Republic of Kenya, 2013). The sub county covers an area of approximately 357.30 square kilometres. The sub-county is divided into 3 administrative regions namely: west, lower and upper divisions. It has a population of 133,041 (Republic of Kenya, 2013). Figure 2 represents map of the area.

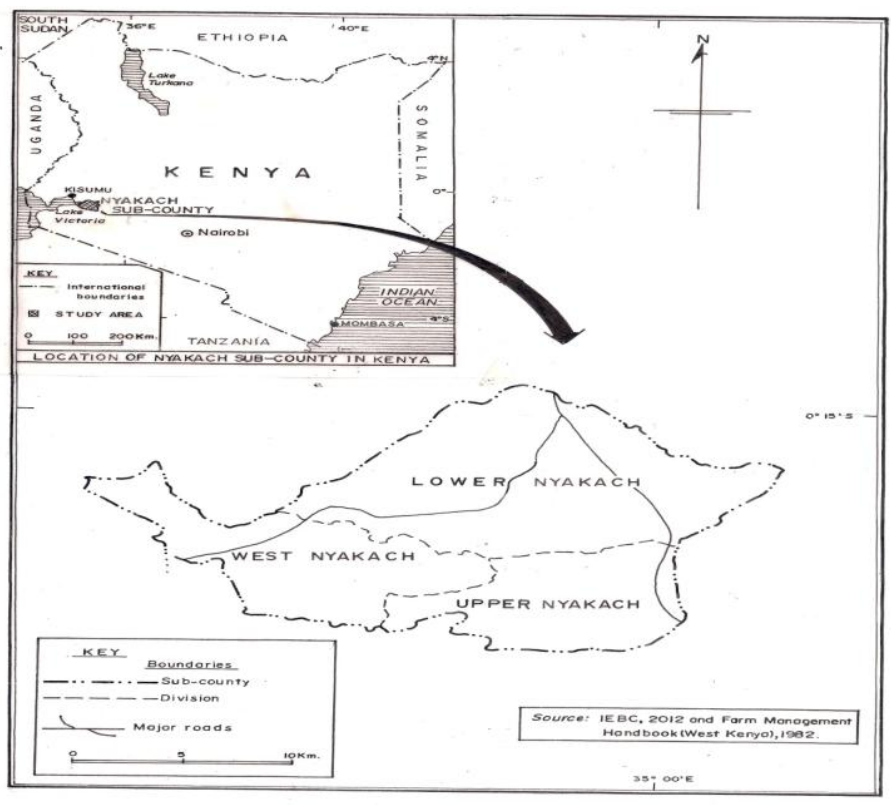

Figure 2: Map of the Study Area

\subsection{Target Population and Sample Size}

Nyakach Sub County is made up of three (3) divisions and each division is managed by a Divisional Social Services Officer (DSSO). All the 3 DSSOs were targeted for the study. Accordingly, the target population of the study therefore was 630 self-help groups with a membership of 9450 with a sample size of 384 .

The focus of analyses for the study was group members with an input of DSSO who formed the key informants though being non-members of SHGs. This study adopted Yamane (1967; cited in Israel, 2013) formula to calculate the sample size of group members as shown below:

$$
\begin{aligned}
& \mathrm{n}=\frac{\mathrm{N}}{1+\mathrm{N}(\mathrm{e}) 2} \\
& \mathrm{n}=\frac{9453}{1+9453(0.05)^{2}}=384
\end{aligned}
$$

Where $n$ is the sample size, $N$ is the population size, and $e$ is the level of precision (0.05).

Stratified random sampling involving dividing the population into homogeneous subgroups and then taking a simple random sample of $f=n / N x$ sample size in each subgroup was used to 
ensure equal representation of each division (Patton, 2002). Where $f$ was the sample size of the sub group; $n$ was the population of the sub group; and $N$ was the target population. The sample distribution of SHG members was as shown in Table 1.

Table 1: Sample Distribution of SHG Members

\begin{tabular}{|c|c|c|c|}
\hline Divisions & $\begin{array}{c}\text { Target } \\
\text { Population } \\
\text { (SHGs) }\end{array}$ & $\begin{array}{c}\text { Membership } \\
\text { (Group members) }\end{array}$ & $\begin{array}{c}\text { Sample } \\
\text { Size }\end{array}$ \\
\hline $\begin{array}{c}\text { Upper } \\
\text { Nyakach }\end{array}$ & 243 & 3631 & 148 \\
\hline $\begin{array}{c}\text { Lower } \\
\text { Nyakach }\end{array}$ & 289 & 4321 & 175 \\
\hline $\begin{array}{c}\text { West } \\
\text { Nyakach }\end{array}$ & 101 & 1501 & 61 \\
\hline TOTAL & 633 & 9453 & 384 \\
\hline
\end{tabular}

\subsection{Data Collection Instruments}

Questionnaire, interview schedule and Key Informant Interview were used for data collection. The study used both open ended and closed ended questionnaire to collect quantitative and qualitative data from the respondents. Questionnaire was deemed suitable in this study since it solicited views of respondents on their experiments with SHGs across the villages in the three divisions (Creswell, 2014). Data was collected from Divisional Social Services Officers (DSSOs) using Key Informant Interviews. Interview schedule was appropriate for the study as it provided in-depth information and a detailed understanding of the issue under research from the SHG leaders. Equally, the key informants' interview provided room for interviewers to delve on issues that demanded detailed inquiry with a room for free airing of concerns of pertinence to the study.

\subsection{Validity of Instruments}

Instrument validity was measured by conducting construct and content validity measurements. Construct validity was attained through operationalization of the research variables. The researcher ensured that the operationalization through translation reflected the true meaning of the constructs. According to Ceswell (2014), construct validity is how the researcher translates or transforms a concept of an idea into function and operating reality. Content validity index (CVI) was used to measure the degree to which the instruments had appropriate items for measuring livelihood of households (Polit \& Beck, 2006). Four experts were asked to rate each scale item in terms of its relevance to the underlying constructs using a 4-point ordinal scale: $1=$ not relevant; $2=$ somewhat relevant; $3=$ quite relevant; $4=$ highly relevant. Then, for each item, the CVI was computed as the number of experts giving a rating of either 3 or 4 (thus dichotomizing the ordinal scale into relevant and not relevant), divided by the total number of experts. The instrument was rated as highly relevant by three out of four judges, giving a CVI of .80 .

\subsection{Reliability of Instruments}

Test/re-test method was done during pilot study with randomly selected 38 respondents to test instrument reliability. Internal consistency of the instrument was determined via the test/re-test reliability index using Cronbach's Alpha coefficient (Cronbach, 1970). Test/re-test method involved administering the same test on the same individuals at two different times (Kumar, 2005). The internal consistency (reliability) of the study generated an Alpha coefficient of 0.849 which was greater than the threshold 0.7 espoused by Nunnaly (Nunnaly, 1978).

\subsection{Data Analysis and Presentation}

Data collected was processed and analyzed using descriptive statistics: mean (M), Standard Deviation (SD) and regressions with the aid of Statistical Package for the Social Sciences (SPSS) tool. The regression model used was as shown below:

$Y_{0}=\beta_{0}+\beta_{1} X_{1+} \beta_{2} X_{2}+\beta_{3} X_{3}+\varepsilon$

Qualitative data obtained from interviews was analysed through Thematic Analysis. This entailed categorization of generated answers into outstanding themes and reported in narrative forms (Braun \& Clarke, 2013).

\section{RESULTS AND DISCUSSIONS}

\subsection{Livelihood of Households}

Table 2: State of Household Livelihoods

\begin{tabular}{|c|c|c|c|}
\hline $\begin{array}{c}\text { Livelihood of SHG } \\
\text { Participants }\end{array}$ & $\mathrm{N}$ & $\mathrm{M}$ & $\mathrm{SD}$ \\
\hline Social Capital & 384 & 3.57 & 1.37 \\
\hline Human Capital & 384 & 3.12 & 1.4 \\
\hline Physical Capital & 384 & 3.39 & 1.31 \\
\hline Natural Capital & 384 & 2.0 & 0.94 \\
\hline Financial Capital & 384 & 4.02 & 0.77 \\
\hline $\begin{array}{c}\text { Overall mean and Std. } \\
\text { Dev }\end{array}$ & 384 & 3.22 & 1.16 \\
\hline
\end{tabular}

The Table2 illustrates that livelihood of the sampled SHG members was at a moderate state $(\mathrm{M}=3.22 ; \mathrm{SD}=0.82)$. The small unit of standard deviation implies that there was no big difference in the opinions of the respondents with regard to their livelihood status. This suggested that SHG participation had moderately improved the livelihood status of the respondents. Based on the mean interpretation scale, the respondents agreed that financial capital $(\mathrm{M}=4.02 ; \mathrm{SD}=.77)$ of their households had improved due to SHG participation. Similarly, the sampled SHG members also agreed that their social capital had improved since joining SHGs $(M=3.57$; $\mathrm{SD}=1.37)$. On the other hand, human capital $(\mathrm{M}=3.12$; $\mathrm{SD}=1.4)$ and physical capital $(\mathrm{M}=3.39 ; \quad \mathrm{SD}=1.31)$ as components of household livelihood had been attained to a moderate extent through SHG participation. 


\subsection{SHGs Structure}

The Independent variable of the study explored the influence of SHGs structure on the livelihood of households (Table 3). The structure was described as SHGs by type (women only, youth only or mixed SHGs); organizations by size (more than 10 members, less than 10 members, or less than 6 members); and organizations by objectives (farmer-based, businessbased, or market-vendor based)

Table3: Influence of SHG Structure

\begin{tabular}{|c|c|c|c|}
\hline Structure of SHG & $\mathrm{N}$ & $\mathrm{M}$ & $\mathrm{SD}$ \\
\hline $\begin{array}{c}\text { SHG organised according to } \\
\text { Type }\end{array}$ & 384 & 3.22 & 1.39 \\
\hline $\begin{array}{c}\text { SHG organised according to } \\
\text { Size }\end{array}$ & 384 & 3.45 & 0.71 \\
\hline $\begin{array}{c}\text { SHGs organised according } \\
\text { to objectives }\end{array}$ & 384 & 3.91 & 0.70 \\
\hline Overall mean and Std. Dev & 384 & 3.53 & 0.93 \\
\hline
\end{tabular}

Findings presented in Table 3 illustrate that the sampled respondents agreed that structure of SHGs $(M=3.53$; $\mathrm{SD}=0.93$ ) have influenced livelihood of their households. Table 3 also indicates that SHGs by type (either youth only groups, women only groups, or mixed groups) have had moderate $(M=3.22 ; S D=1.39)$ influence on livelihoods of households. This suggests that SHGs formed by women, youth or mixed members have influenced livelihood of some households while for others, it had not. The table also indicates that the sampled respondents agreed that the size of SHGs $(M=3.45 ; \mathrm{SD}=0.71)$ have influence on livelihood of households. Table 3 also illustrates that the sampled respondents agreed $(\mathrm{M}=3.91 ; \mathrm{SD}=0.7)$ that objective based SHGs (that is, membership bound by common objective) are more livelihood responsive $(\mathrm{M}=3.91 ; \mathrm{SD}=0.7)$. This seems to imply that objective driven SHGs are more beneficial to members' livelihoods.

During interviews with the Divisional Social services officers (DSSOs), it emerged that SHGs based on common income activities like market vending, farmers, crafts or bodaboda (motor cycle) operators were more focused and were able to meet the social and economic needs of their members. An outstanding theme emerging from one of the key informant interviews was:

Groups comprising members such as open market traders, bodaboda riders and repairers, farmers and shopkeepers seem to be more stable and often meet the needs of their membership. This is due to the fact that such groups are formed based on commonality of objectives and purpose (DSSO 1).

It can be concluded from the statement of DSSO 1 that the shared purpose inherent upon groups formed on the basis of objectives was the drive behind stability and success among such groups. Indeed, such SHGs formed on the basis of the objectives have been associated with improved livelihoods of members across the globe.

In another interview, the researcher deduced that most of the SHGs were formed in the study area with the objective of making better the businesses they were undertaking. Most of the groups were composed of persons whose income levels were low, illiterate or semi illiterate, were lacking employment, and were unable to access financial services. An outstanding theme that emerged from the KII was:

Groups in the sub county have helped members to accumulate savings and get small loans which enable them acquire domestic assets like livestock. In turn, the households'income improves and their standards of living get changed for the better (DSSO 3).

The statement attributed to DSS0 3 seems to imply that SHGs on the basis of shared objectives have had improved livelihood in their households. Perhaps concern over low level of income is sufficiently endorsed as the drive towards participation in SHGs.

The researcher further carried out correlation analysis to determine the direction of the relationship between SHG structure and livelihood of household's members at 0.05 significance level. Table 4 presents the correlations between SHG structure and livelihood of households' members.

Table 4: Correlations between SHGs Structure and Livelihood of Households

\begin{tabular}{|c|c|c|c|}
\hline \multicolumn{2}{|c|}{ Correlation } & \multirow{2}{*}{$\begin{array}{c}\begin{array}{c}\text { Structure of } \\
\text { SHGs }\end{array} \\
1\end{array}$} & \multirow{2}{*}{$\begin{array}{c}\begin{array}{c}\text { Liveliho } \\
\text { od of } \\
\text { Househo } \\
\text { lds }\end{array} \\
.427^{* *} \\
\end{array}$} \\
\hline \multirow{3}{*}{$\begin{array}{l}\text { Structure of } \\
\text { SHGs }\end{array}$} & $\begin{array}{c}\text { Pearson } \\
\text { Correlation } \\
\end{array}$ & & \\
\hline & $\begin{array}{l}\text { Sig. }(2- \\
\text { tailed) }\end{array}$ & & .000 \\
\hline & $\mathrm{N}$ & 384 & 384 \\
\hline \multirow{3}{*}{$\begin{array}{l}\text { Livelihood of } \\
\text { households }\end{array}$} & $\begin{array}{c}\text { Pearson } \\
\text { Correlation }\end{array}$ & $.427^{* * *}$ & 1 \\
\hline & $\begin{array}{l}\text { Sig. }(2- \\
\text { tailed) }\end{array}$ & .000 & \\
\hline & $\mathrm{N}$ & 384 & 384 \\
\hline
\end{tabular}

Key: $r$ values of:

From the results presented in Table 4, the output indicated a significant $(n=384 ; \mathrm{r}=.427 ; \mathrm{p}<0.05)$ but a low correlation between SHG structure and livelihood of households. This suggests that even though structure of SHGs has influence on livelihoods of households, the influence is low and must be supported with other factors to bring out positive outcome in the form of social protection.

\section{DISCUSSIONS}

The study found that structure of SHGs influences livelihood of households. Financial capital and social capital of the SHG members improved owing to participation in the groups. Similarly, it was established that the size of SHGs and the groups formed on the basis of objectives influenced livelihood 
of households in the study area. This seemed to imply that size and objective driven SHGs were more beneficial to members' livelihoods. The theory of collective action stipulating joint efforts in empowerment endeavors was critical in ensuring improvement in performance of SHGs in terms of credit repayment and disbursement (Bharamappanavara \& Jose, 2015). This finding tends to concur with Feroze et al (2011) which established that group size was one of the factors with significant influence on SHG loan repayment in the state of Haryana. SHG size seemed to have an influence in group performance including impact on household livelihood. However, this finding may not be said to concur with a study by Hossain et al (2016) which found that impacts of agricultural credit on productivity and livelihood of small, marginal, and landless tenant farmers in Bangladesh were heterogeneous over household's headship, tenancy status, and farm size. Nevertheless, the findings were in consonance with Rathinam and Victor (2014) which found that dairy dependent women SHGs often got empowered by taking up dairying as an income generating activity.

\section{RECOMMENDATION}

The gist of this study was based on the role of SHGs' structures in improving the livelihoods of households in Nyakach sub-county, Kenya, paying close attention to size, type and SHGs based on objectives. However, this study acknowledges that notwithstanding the contributions of SHGs in enhancing livelihoods of households, other factors that are not related to SHGs' structure also play significant roles. There is therefore need for future studies to delve into other structures of SHGs such as age, gender, income, marital status, employment type and religion and how they impact the livelihoods of households. The study also recommends further research that would explore SHG members' empowerment through education, training and entrepreneurial skills development for enhanced livelihood and socio-economic well-being

\section{CONCLUSIONS}

The study concludes that financial as well as social capital were major components influenced by structure of SHGs. It is also concluded that the size and objective-based SHGs have had influence on livelihood of households. Organizations formed by women were the only type-based SHGs with significant influence on livelihood of households. The study finally concluded that influence of structure of SHGs was heterogeneous, and was dependent on various contextual factors.

\section{REFERENCES}

[1] Agrawal, N., Thakur, S. and Singh, R. (2016). Empowerment of women through self-help group: A case study. Progressive Research - An International Journal, 11 (2), 266-268

[2] Alison, E. and Nambiar, D. (2013). Collective action and women's agency: A background paper. Women's Voice, Agency and Participation Research Series 4.

[3] Atieno, P.O. (2017). Self Help Groups and household asset acquisition and income among women group members in Kisumu
East Sub County, Kenya. Journal of Education and Practice, 8 (3), $21-27$.

[4] Badejo, A.F., Majekodunmi, A.O, Kingsley, P., Smith, J. and Welburn, S.C. (2017). The impact of self- help groups on pastoral women's empowerment and agency. A study in Nigeria. Pastoralism: Research, Policy and Practice, 7(28), 1 - 12.

[5] Armendariz de Aghion, B., \& Morduch, J. (2005). The economics of microfinance.Cambridge, MA: The MIT Press.

[6] Beaman, L., Karlan, D., Thuysbaert, B. and Udry, C. (2014). SelfSelection into Credit Markets: Evidence from Agriculture in Mali. National Bureau of Economic Research (NBER) Working Paper 20387.

[7] Bharamappanavara, S.C. and Jose, M. (2015). Group dynamics and collective performance of self-help groups under different microcredit delivery models in Karnataka. Agricultural Economics Research Review, 28 (1), 1 - 12.

[8] Braun, V. \& Clarke, V. (2013). Using thematic analysis in Psychology. Qualitative Research in Psychology, 3 (2), 77-101.

[9] Carney, D. (1998). Implementing the sustainable rural livelihoods approach. Paper presented to the DfID Natural Resource Advisers' Conference. London: Department for International Development.

[10] Creswell, J. (2012). Educational Research: Planning, Conducting and Evaluating Qualitative and Quantitative Research (4th ed.). Boston: Pearson Education Inc

[11] Creswell, J. W. (2014). Research design: qualitative, quantitative, and mixed methods approach. Handbook of mixed methods in social and behavioral research (pp 209-240) Thousand Oaks, Calfornia: SAGE Publications.

[12] Cronbach, L. J. (1970). Essentials of Psychological Testing (third edition). New York: Harper \& Row.

[13] De Hoop, T, Brody, C, Tripathi, S, Vojtkova, M and Warnock, R, (2019). Economic self-help group programmes for improving women's empowerment, 3ie Systematic Review Summary 11. London: International Initiative for Impact Evaluation(3ie).Available at: doi:http://doi.org/10.23846/SRS011.

[14] Fagan, P., Quinn-Gates, H., Rebsso, M. \&Cromie, S. (2021). The Impact of self-help groups on the psychosocial well-being of female members in Ethiopia.

[15] Feroze, S.M., Chauhan, A.K., Malhotra, R. and Kadian, K.S. (2011). Factors influencing group repayment performance in Haryana: Application of Tobit Model. Agricultural Economics Research Review, 24, 57-65.

[16] Haile, H. B., Bock, B., \&Folmer, H. (2012). Microfinance and female empowerment: Do institutions matter? Women's Studies International Forum, 35(4), 256-265.

[17] Hossain, M., Maleky, M.A., Hossain, A., Reza, H. and Ahmed, S. (2016). Impact assessment of credit program for tenant farmers in Bangladesh: Evidence from a field experiment. CIRJE Discussion Papers: http://www.cirje.e.utokyo.ac.jp/research/03research02dp.html

[18] Israel, G. (2012). Determining Sample Size. EDIS Website. https://edis.ifas.ufl.edu

[19] Kaur, L. and Bajwa, H.S. (2016). Rural Development - Self Help Group success story. Asian Journal of Agricultural Extension, Economics \& Sociology, 14(1), 1-9.

[20] Kumar, C. R. (2005). Research Methodology. New Delhi: APH Publishing Corporation.

[21] Mushumbusi, P. K. and Kratzer, J. (2013). Empowering women through microfinance: Evidence from Tanzania. ACRN Journal of Entrepreneurship Perspectives, 2 (1), 31-59.

[22] Nithyanandhan, S.H. and Mansor, N. (2015). Self Help Groups and Women's Empowerment. Institutions and Economies: https://www.researchgate.net/publication/283026425.

[23] Nunnaly, J.C. (1978) Psychometric Theory (2nd ed) New York: McGraw-Hill

[24] Ofuan. J. I. \&Izien. F. O. (2016). Firm Age, Size and Profitability Dynamics: A Test of Learning by Doing and Structural Inertia Hypotheses. Business and Management Research, 5, (1), 64 - 79.

[25] Patton, M. Q. (2002). Qualitative research and evaluation methods (3rd ed.). Thousand Oaks, CA: Sage. 
[26] Polit, D.F. and Beck, C.T. (2006). The Content Validity Index: Are you sure you know what's being reported? Critique and recommendations. Research in Nursing \& Health, 29, 489-497.

[27] Rahman, S. and Akter, S. (2014). Determinants of livelihood choices: an empirical analysis from rural Bangladesh. Journal of South Asian Development, 9(3), 287-308.

[28] Rathinam, U and Victor, U.D. (2014). Dairy Dependent Self -Help Groups in Pondicherry: A tool for Economic Empowerment International Journal of Agriculture Innovations and Research, 3 (2), $407-414$.

[29] Republic of Kenya (2010). Poverty Reduction Strategy Paper 2013-2018. Nairobi: Central Bureau of Statistics.

[30] Republic of Kenya (2013). Poverty Reduction Strategy Paper, 2013-2018. Nairobi: Central Bureau of Statistics

[31] Republic of Kenya (2019). Nyakach District Development Plan. Nairobi: Central Bureau of Statistics.
[32] Scoones, I. (2009). Livelihoods perspectives and rural development. The Journal of Peasant Studies, 36, 171-196.

[33] Stella, B., Aggrey, N. and Eseza, K. (2014). Firm size and rate of growth of Ugandan manufacturing firms.Journal of Applied Economics and Business Research, 4 (3), 178- 188.

[34] Tiwari, A. and Arora, J. (2015). Why are the Self Help Groups (SHGs) in decline? A case study of SHGs in Gurgaon. Research on Humanities and Social Sciences, 5 (1), 77 - 86.

[35] Ugbomeh, G.M.M., Achoja, F.O., Ideh, V. and Ofuoku, A.U. (2008). Determinants of loan repayment performance among women self-help groups in Bayelsa State, Nigeria. Agriculturae Conspectus Scientificus, 73 (3), 189-195.

[36] Yamane, T. (1967): Statistics: An Introductory Analysis. $2^{\text {nd }}$ Edition. New York: Harper and Row 